\title{
PANELISTS, ARBITRATORS, JUDGES: A RESPONSE TO JOOST PAUWELYN
}

\author{
Giorgio Sacerdoti*
}

I must state from the outset that I am not convinced that an analysis like the one conducted by Joost Pauwelyn, though valuable from a statistical and quantitative point of view, is really apt to explain the different functioning of legal institutions, their efficiency in term of results achieved in relation to objectives, the satisfaction of the various group of users and the reasons for their being subjected to criticism. ${ }^{1}$ The different architecture of the trade and investment systems reflects different constituencies, objectives and needs. Praise and criticism come from different groups of users and nonusers, and they change over time due to changing perceptions, objectives, and interests.

As to the change of attitudes in time, one can recall the sharp reactions in the United States after the loss of high profile trade disputes at the World Trade Organization (WTO) (steel, antidumping). The Appellate Body was accused of "judicial activism" and of improperly "filling gaps" that negotiators had left open in the Uruguay Round. ${ }^{2}$ At the same time, in various WTO Member countries, NGOs and others speaking for "civil society" decried the "subordination" of environmental and social interests, such as the protection of labor rights and human rights, to the interests of trade and all of it adjudicated by a trade court. In terms not so different from the U.S. critics, a French magazine referred to, "the secret court that does and undoes the affairs of the whole planet." After the Seattle WTO Ministerial meeting of 1999, which was met by hostile mass demonstrations, associations of farmers demonstrated in front of the WTO building in Geneva, heavily guarded by the local police, culminating in a Korean peasant immolating himself in front of the gates.

However, later the winds changed, and criticism was addressed to specific decisions rather than to the entire dispute settlement system. This happened due to two developments. First, the United States had extensively (and successfully) resorted to the WTO dispute settlement system, especially to push China to open its market to U.S. exporters. Secondly, the Appellate Body has shown itself to be sensitive towards nontrade values under Article XX of the General Agreement on Tariffs and Trade (GATT), General Exceptions, by rectifying several panel decisions relating to trade and the environment. ${ }^{3}$ The WTO has thus become popular in the eyes of some

* Senior Professor of International Law, Bocconi University, Milan. The author of this essay has been a member of the WTO Appellate Body from 2001 to 2009 (its chairman in 2006-2007) and has acted as investment arbitrator several times both at ICSID and under other institutional rules. I have recalled the differences between these two roles in my contribution in the recent volume in honor of Judge Charles Brower: Giorgio Sacerdoti, From Law Professor to International Adjudicator: The WTO Appellate Body and ICSID Arbitration Compared, A Personal Account, in, PRACTISING VIRTUE - INSIDE INTERNATIONAL ARBITRATION 204 (David D. Caron et al. eds., 2015). I acknowledge the assistance of Carlo de Stefano, Ph.D. candidate at Bocconi University for the revision of the present contribution.

Originally published online 13 April 2016.

${ }^{1}$ Joost Pauwelyn, The Rule of Law Without the Rule of Lawyers? Why Investment Arbitrators are from Mars, Trade Adjudicators from Venus, 109 AJIL 761, 761 (2015).

${ }^{2}$ For a critical view, see Richard H. Steinberg, Judicial Lawmaking at the WTO: Discursive, Constitutional, and Political Constraints, 98 AJIL 247 (2004).

3 Appellate Body Reports, United States_-Import Prohibition of Certain Shrimp and Shrimp Products, WT/DS58/AB/R (Adopted Nov. 6, 1998); European Communities-Measures Affecting Asbestos and Asbestos-Containing Products, WT/DS135/AB/R (Adopted Apr. 5, 2001); Brazil-Measures Affecting Imports of Retreaded Tyres, WT/DS332/AB/R (Adopted Dec. 17, 2007). 
of its former harshest critics. However, the selection method for panelists and their qualifications was not part of the initial controversy about WTO dispute settlement, be it of criticism or praise.

A similar picture can be detected with Investor-State Dispute Settlement (ISDS). The Organisation for Economic Co-operation and Development initiative in the 1990's, the Multilateral Agreement on Investments, was killed on the basis of the argument that it would grant preferential treatment to multinational corporations. ${ }^{4}$ More recently has there been the criticism that "the case will be heard in a private international tribunal, composed of unelected corporate lawyers." 5

In this historical perspective of changing attitudes it is ironic that the W'TO dispute settlement system, specifically the Appellate Body, has been taken by the European Commission as the model of a permanent doublestage investment court proposal to replace ISDS in the Transatlantic Trade and Investment Partnership (TTIP) negotiations and in other bilateral trade and investment agreements currently negotiated by the European Union. ${ }^{6}$ The personal profile of the adjudicators is not the central element of criticism that the idea of a permanent court is meant to address. The central change in this respect is that investment disputes would be heard by a tribunal composed of individuals (judges or arbitrators) selected by the state parties to the treaty, excluding any role for investors in the selection, although investors are by definition the claimants within this mechanism. By contrast, a canonical model of ISDS was agreed by the twelve negotiating and signatory states for the TransPacific Partnership, with few adjustments, showing that ISDS and its method of selection of ad hoc arbitrators by the parties has not yet been repudiated.

Sociological analysis may complement a legal institutional examination, but it cannot replace it. In fact, the analysis by Pauwelyn leads to an apparently absurd conclusion. The system that attributes the solution of disputes to the apparently least competent, randomly chosen, geographically nonrepresentative adjudicators is the one that enjoys the highest level of acceptance. The one that resorts to arbitrators directly appointed by each party, who are expected to choose the most competent experts in the field, is instead subject to increasing criticism.

My central points of perplexity are twofold:

First, I am not convinced by the premise that the WTO panel system is functioning so well to the satisfaction of the individual users and the larger constituency interested in trade disputes. Indeed, one of the most criticized features of the system today is the profile and selection of the panelists. Nor am I convinced by the other face of the argument - that investment arbitration, specifically the International Centre for the Settlement of Investment Disputes (ICSID), is suffering from such criticism as to imperil its existence.

Secondly, I am not convinced that the selection of both WTO panelists and ICSID investment arbitrators and their individual qualifications are as "unbalanced" as Pauwelyn presents them, based on statistics on nationality. I believe that these data amplify whatever imbalance may exist and leave out important key elements. Moreover, the analysis should be completed by taking into account the qualifications and origins of the Appellate Body members and of annulment committee members at ICSID in view of the decisive importance of these two institutions in the overall operation of the two systems. Taking also their members into account, the universe of WTO adjudicators would appear more similar as to nationality and qualifications to investment

\footnotetext{
${ }^{4}$ For a review, see UN ACCORD MULTILATERAL SUR LES INVESTISSEMENTS: D'UN FORUM DE NÉGOCIATION À L'AUTRE?, (Société française pour le droit international ed., 1996).

5 These statements were made in reaction to the announcement by TranCanada Corporation that it intends to challenge under NAFTA Chapter 11 the cancellation by the U.S. Government in November 2015 of the controversial Keystone XL pipeline, see Magda Stokiewicz, How trade deals threaten democracy and climate, EUOBSERVER (Jan. 8, 2016).

${ }^{6}$ The EU proposal of a permanent international tribunal with appeal to hear investment disputes has been accepted by Canada in the final text of the Canada-EU Comprehensive and Economic Trade Agreement.
} 
arbitrators. Finally, statistical data cannot evaluate whether or not the different selection processes reflect the different requirements for proper adjudicators in each system.

There is no doubt that the WTO dispute settlement system is showing signs of stress - in part a victim of its own success - while multilateral negotiations in the Doha Round have not reached their objectives even after fifteen years. The most pressing problem at present in relation to dispute settlement, which has been raised more than once by WTO members in the Dispute Settlement Body (DSB), is that of the delays in the process at the panel stage. This shortcoming is due at least in part to the lack of legal resources in the Secretariat to staff the many panels that are being established and which face more and more complex disputes. ${ }^{7}$

As a result, panel proceedings that according to the rules should take not more than six months (Article 12.9 of the Dispute Settlement Understanding (DSU)), and which in practice have taken around one and a half years from the formal establishment of the panel to the circulation of its report, may now take between two and three years. Nor is this necessarily the end of the matter since in about two thirds of the cases one or both parties avail themselves of the right to appeal. The Appellate Body, in turn, is finding it increasingly difficult to respect the short ninety-day period prescribed for issuing its own reports, not to speak of the further proceedings to be followed by a successful claimant when full implementation by the losing party does not occur. ${ }^{8}$ The time lag for obtaining effective redress against domestic measures in breach of W'TO commitments undermines the value of any favorable decision, which is especially damaging in respect of temporary measures such as antidumping duties. More broadly, this dysfunctional operation of the WTO dispute settlement system, in disregard of one of its basic tenets and praised features, namely its speed, may undermine the whole operation of the system and recourse to it as the key instrument for ensuring respect for trade commitments. ${ }^{9}$

The inability of the current system to cope with the increase in litigation is due in large part to its structure, which at the panel level is still basically patterned after the GATT model. GATT panels were picked ad hoc, and drawn almost exclusively from trade diplomats in Geneva reflecting the nonlegal character of trade disputes

7 In the meeting of the DSB on 31 August 2015 Korea complained that in DS488, a complaint by Korea of U.S. antidumping measures,

the Secretariat had informed Korea that the panel established on 25 March 2015 would not begin its work until the end of 2016, at the earliest, a date some 15 months from the time Korea had been notified of the delay . . . not because the panelist were unavailable, but due to the constraints affecting the Secretariat.

Korea pointed out that this "remarkable, extraordinary, unreasonable delay" in light of both the DSU provisions and the economic reality, just for the case to get started, "was almost twice as long as the period foreseen by Art. 12.9 DSU between the establishment of the panel and the circulation of the report." (WTO DSB, Minutes of the Meeting, WTO Doc. WT/DSB/M/367 (Aug. 31, 2015)).

8 As an example, at a recent DSB meeting in mid-2015 Canada complained that after four and a balf years since the establishment of the panel the COOL (country-of-origin labeling) dispute with the United States was still far from being settled: after the panel, the appeal, the fixing by an arbitrator of the reasonable period of time for the United States to comply (which was not respected), a compliance panel (Article 21.5 DSU) against the United States by Canada and Mexico (the other complainant), which found that the measure taken by the United States had not brought compliance (but possibly even worsened the breach). The arbitration panel (Article 22.6 DSU) was at the time just starting its work (later concluded in December 2015) to establish whether the countermeasures announced by Canada and Mexico were excessive in comparison with the trade loss caused to them by the COOL measure, as submitted by the United States. Shortly after the arbitration had been concluded, President Obama announced on 18 December 2015 a radical change of the COOL legislation putting it in conformity with U.S. obligations.

9 The Director-General made a lengthy and detailed statement at the DSB meeting of 28 October 2015 in which he made the point that the problems would not be resolved just through administrative measures and shifting of resources within the Secretariat as he had been actively doing. Several Members acknowledged the problem and decried its negative consequences on the effectiveness of the DSB though abstained from launching any ideas for tackling more seriously the problems. 
in those days. ${ }^{10}$ As pointed out by Pauwelyn, even today, panelists are not professional judges or arbitrators: about half of them are trade diplomats based in Geneva, who do not necessarily have a law degree. ${ }^{11}$

As a consequence, panelists rely heavily on the lawyers of the Secretariat assigned to each panel (normally two, one senior and one junior) for research, to organize hearings, and for drafting. In the abstract, this approach might appear to contradict the professionalization and legalization of the system, but WTO Members are attached to the tradition of being judged by their peers. However, with the current flow of cases, this system will increasingly be unable to perform its functions unless the Secretariat is expanded or panelists are available on short notice and are able to meet for longer periods and engage more actively in drafting.

Let's compare this situation with that of permanent international courts and international commercial and investment arbitration. In international courts, the judges are mostly full-time and they are assisted by a centralized secretariat and/or by one or two full-time individual clerks. In international arbitration, the secretariat support is much less, even compared to the WTO; arbitrators are selected among recognized experts in the field who are able to research and draft by themselves, possibly with the support of personal assistants from universities or their own law offices. The support of a secretariat (for example ICSID or the International Chamber of Commerce) is often limited to procedural matters and formal review of a decision prepared by the arbitrators themselves.

The WTO process would also be facilitated by broadening the pool of potentially available panelists. ${ }^{12}$ The first change would be to permit nationals of third parties to a dispute to be selected as panelists, provided they are not government officials. At the present time, nationals of the litigating parties or of third parties can be appointed only with the consent of the parties (Article $8.3 \mathrm{DSU}$ ). ${ }^{13}$ Besides depriving the system of competent experts who could act as panelists, this restriction leads to choosing the panelists predominantly from a small group of countries that are rarely involved in disputes. This leaves the adjudicators unrepresentative of the geography of the litigants or of the issues raised.

Although the qualifications of the panelists and their cumbersome mode of selection (jointly by the parties or ultimately by the DSB) are not the most positive aspects of WTO dispute settlement, WTO Members generally like this system and show reluctance for change. Until now, the active management by the Secretariat of the selection process and of the production of the panels' reports has maintained a reasonably satisfactory operation. Moreover, using panelists from countries which are somehow "marginal" in the WTO (not necessarily all developing countries) allows countries that are rarely involved in disputes to contribute through their experts, a kind of participation that is beneficial because it enhances the feeling of "ownership" by the Members at large and therefore the perception of the system being legitimate.

At the same time, I do not agree with Pauwelyn that the fact that statistics show that WTO panelists are "predominantly low-key diplomats from developing countries" is significant per se. First, WTO panelists come often from major economies (such as Argentina, Brazil, South Africa) and are senior officials in their domestic administrations, such as antidumping officials. In an "actively managed" adjudication system such as the WTO

\footnotetext{
${ }^{10}$ Small but important efficiency innovation could also concern the composition of panels, regarding which parties often disregard the provision of Article 8.6 that "[t]he parties to the dispute shall not oppose nominations suggested by the Secretariat under the same provision except for compelling reasons," thus causing additional delays. The suppression of the "Interim Review Stage" (Article 15) which has become pointless with the introduction of appeal would also speed the process.

11 As a consequence, they are not paid, if they are employed by their governments, because they are considered to be put by the latter at the disposal of the WTO. This is an additional reason why the top officials are usually not available for selection.

${ }^{12}$ See Reto Malacrida, WTO panel composition: searching far and wide for administrators of world trade justice, in A HISTORY OF LAW AND LAWYERS IN THE GATTT/WTO 311 (Gabrielle Marceau ed., 2015).

13 This means that in practice, American, European, Japanese, Canadian, and Chinese potential panelists are hardly ever appointed since the respective countries almost always participate as third parties to proceedings when they are not main parties.
} 
panel system, individual personalities, reputation, and even competence as arbitrators are not decisive. You do not need legal stars when the subject matter is narrow, the procedure is clear and the legal staff of the Secretariat is the depository of the relevant knowledge. ${ }^{14}$

In ad hoc arbitration, both interstate and ISDS, each party appoints individually one member of the tribunal. Especially in high profile cases, because of the political sensitivity of the issues raised and of the amounts claimed, candidates are sought on the basis of competence, previous experience, and reputation among peers. The same is true in a different way for the choice of the presiding arbitrator, be it jointly by the parties or by the appointing institution. One, therefore, expects the practice of repeated appointments of prominent arbitrators. Contrary to popular perception, a number of these arbitrators have had judicial experience in other fora from the International Court of Justice to the WTO Appellate Body. Many members of annulment committees, who are appointed by the Chairman of the Administrative Council of ICSID from the Panel of Arbitrators composed of member states' designees, ${ }^{15}$ are not based in North America or Western Europe but come from the region to which a respondent state belongs, such as Latin America. ${ }^{16}$

Similarly, relying on statistics concerning nationality in respect of ICSID investment arbitrators is not particularly significant. The different selection methods of the adjudicators in trade versus investment disputes resulting in their different features reflect the structural differences between the two systems. It cannot be said in abstract that one system is better than the other.

In fact, while the authority of WTO decisions is based on the quality of the institution and the predictability of a stable body of case law, within ISDS respect for ad hoc awards is grounded in the persuasiveness of the reasoning underpinning the award. Since international investment law is rooted in customary international law principles and the rather general terms of bilateral investment treaties, more robust knowledge and familiarity with international law at large, both substantive and procedural, is required than from panels applying specific WTO agreements under the ultimate control of the Appellate Body.

${ }^{14}$ See for instance the Repertory of WTO law updated regularly by the Secretariat (WORLD TRADE ORGANIZATION, I-II WTO ANALYTICAL INDEX, GUIDE TO WTO LAW AND PRACTICE, (2d ed., 2007), besides the one issued by the Appellate Body (WTO APPELLATE BODY, REPERTORY OF REPORTS AND AWARDS, 1995-2013 (5th ed., 2015).

${ }^{15}$ Convention on the Settlement of Investment Disputes Between States and Nationals of Other States art. 52, Mar. 18, 1965,575 UNTS 159 .

16 Since ISDS arbitrators, like commercial arbitrators, do not enjoy the same level of administrative and legal support that the WTO Secretariat provides, this encourages the growth of arbitration specialists with their own "arbitration boutiques" or connected to specialized law firms avoiding the risk of conflict of interest that large firms generate. 